\title{
Carbon mineralization and carbon dioxide emission from organic matter added soil under different temperature regimes
}

\author{
Md. Babu Hossain ${ }^{1}$ (1) $\cdot$ Md. Mizanur Rahman ${ }^{1}$ Jatish Chandra Biswas ${ }^{2}$ • \\ Md. Main Uddin Miah ${ }^{1} \cdot$ Sohela Akhter ${ }^{3}$ Md. Maniruzzaman ${ }^{2}$. \\ Apurba Kanti Choudhury ${ }^{3}$ - Faruque Ahmed ${ }^{3} \cdot$ Md. Humayn Kabir Shiragi $^{1}$. \\ Naveen Kalra ${ }^{4}$
}

Received: 22 June 2017/ Accepted: 6 October 2017/Published online: 16 October 2017

(c) The Author(s) 2017. This article is an open access publication

\begin{abstract}
Purpose Information on carbon dioxide $\left(\mathrm{CO}_{2}\right)$ emission from different organic sources and their temperature sensitivity to decomposition is scarce in Bangladesh. Therefore, this study quantified the rates of $\mathrm{CO}_{2}$ emission and carbon (C) degradation constants from different organic material mixed soils at variable temperatures in two laboratory experiments.

Methods The first experiment was conducted at room temperature for 26 weeks to study $\mathrm{CO}_{2}$ emission and $\mathrm{C}$ mineralization using vermicompost, chicken manure, cow dung, rice straw, and rice husk biochar. Weekly $\mathrm{CO}_{2}$ emission was measured by alkali absorption followed by acid titration. The second experiment comprised two factors, viz. four organic materials (vermicompost, chicken manure, cow dung, and rice straw) and six temperature regimes $\left(25,30,35,40,45\right.$, and $\left.50{ }^{\circ} \mathrm{C}\right)$. Organic materials at $2.5 \mathrm{~g} \mathrm{C} \mathrm{kg}^{-1}$ soil were mixed in both experiments.

Results $\mathrm{CO}_{2}$ emission reached the peak at 5th weeks of incubation and then decreased with irregular fashion until 21 st week. The $\mathrm{C}$ emission loss followed in the order of chicken manure $>$ rice straw $>$ vermicompost $>$ cow dung $>$ rice husk biochar, and $\mathrm{C}$ degradation constants indicated the slower decomposition of rice husk biochar
\end{abstract}

Md. Mizanur Rahman

mizan@bsmrau.edu.bd

1 Department of Soil Science, Bangabandhu Sheikh Mujibur Rahman Agricultural University, Gazipur 1706, Bangladesh

2 Bangladesh Rice Research Institute, Gazipur 1701, Bangladesh

3 Bangladesh Agricultural Research Institute, Gazipur 1701, Bangladesh

4 Krishi Gobeshona Foundation, Dhaka 1215, Bangladesh compared to cow dung, vermicompost, chicken manure, and rice straw. Temperature positively enhanced the mineralization of organic materials in the order of $50>45>40>35>30>25{ }^{\circ} \mathrm{C}$, which contributed to higher availability of soil phosphorus.

Conclusions High temperature increased mineralization of tested organic materials. Because of slower decomposition rice husk biochar, cow dung and vermicompost application can be considered as climate-smart soil management practices that might help in reducing $\mathrm{CO}_{2}$ emission from soil.

Keywords Organic materials - Carbon degradation - Soil properties $\cdot$ Climate-smart soil management

\section{Introduction}

Carbon mineralization rate can be used to quantify the impact of different organic and inorganic materials on soil functions. Chemical, physical, and biological alteration and breakdown caused mineralization of soil organic matter (SOC) and increased $\mathrm{CO}_{2}$ emission (van Gestel et al. 1991), which accounted for about $60 \%$ of total greenhouse impacts (Rastogi et al. 2002). Although vegetation and soil act as sink and storage of air $\mathrm{CO}_{2}$ (Franzluebbers and Doraiswamy 2007), its emission has increased greatly in the last few decades. Methane $\left(\mathrm{CH}_{4}\right), \mathrm{CO}_{2}$, and nitrous oxide $\left(\mathrm{N}_{2} \mathrm{O}\right)$ trap outgoing infrared radiation from the earth, and the atmosphere becomes warmer. So, emissions of $\mathrm{CO}_{2}$ and other greenhouse gases need to be reduced.

The rate of soil $\mathrm{C}$ emission is strongly influenced by the amount and properties of added organic materials, soil processes, and environmental conditions, especially temperature and water availability (Agehara and Warncke 
2005). Organic materials begin to decompose when residues are added to a soil that results in emission of different gases, especially $\mathrm{CO}_{2}$ depending on microbial activities associated with soil moisture and temperature (Rahman 2013a). Therefore, predicting carbon mineralization of organic materials returned to soils is vital for foreseeing $\mathrm{CO}_{2}$ emissions (Hassan 2013). Net reduction in $\mathrm{CO}_{2}$ emission means increased soil $\mathrm{C}$ storage, which is commonly known as $\mathrm{C}$ sequestration in agriculture or terrestrial $\mathrm{C}$ sequestration. Carbon sequestration is the process of capturing atmospheric $\mathrm{CO}_{2}$ by plants and storage of biomass in soil as organic materials (Lal 2004). The fraction of plant biomass returned to soil is transformed into more stable humic substances and contributed to the formation of different organo-mineral complexes and microaggregates which protect soil carbon for further mineralization and increase C sequestration (Lal 2016). It has been emphasized that $\mathrm{C}$ sequestration is essential to recuperate soil quality, augment agronomic productivity, and use efficiency of inputs like fertilizers and water and thus helps maintain or restore the capacity of soil to achieve maximum production and healthy environment. The $\mathrm{CO}_{2}$ released from soil through microbial decomposition of organic materials contributes $99 \%$ of the total emission and thus reduces soil organic pool. The loss of soil $\mathrm{C}$ affects soil structure, fertility, and productivity. Therefore, C sequestration is the prime requirement to conserve soil organic matter (SOM) not only for a source of plant nutrients but also to act as a potential sink of atmospheric $\mathrm{CO}_{2}$ (Kundu et al. 2006; Lal 2006; Gnanavelrajah et al. 2008).

Mineralization of different organic materials varies with soil types and crop husbandry. Among the factors that control mineralization of organic materials are composition or quality of residues added, soil temperature and water availability, and soil properties (Cabrera et al. 2005). Besides, organic compounds added to soil exhibit a wide range of kinetic properties and temperature sensitivity for their decomposition (Davidson and Janssens 2006). The SOM decomposition increases with higher temperature which is considered as a critical issue for agricultural sustenance in future (Conant et al. 2011). Information on high temperature-dependent decomposition of different organic materials is needed for developing soil $\mathrm{C}$ models, predicting the effects of higher temperature on soil $\mathrm{C}$ stocks, and improving knowledge on $\mathrm{C}$ cycling for soil $\mathrm{C}$ management and mitigation of global warming. We hypothesized that $\mathrm{CO}_{2}$ emission from soil would vary with different organic materials and temperature levels during decomposition process. Moreover, proper management of such organic materials may improve soil biodiversity, microaggregation, and reduction in $\mathrm{CO}_{2}$ emission from soil (Rastogi et al. 2002; Lal
2004; Russell et al. 2005). The national and global concerns about the effects of $\mathrm{CO}_{2}$ emission have spawned research avenues on soil organic $\mathrm{C}$, its transformation under different soil and crop environments. Therefore, the objectives of the present study were to determine $\mathrm{CO}_{2}$ emission from organic material mixed soils and quantify their $\mathrm{C}$ degradation rate constants under different temperature regimes in the laboratory.

\section{Materials and methods}

\section{Description of the study soil and organic materials}

The mineralization of cow dung, chicken manure, vermicompost, rice straw, and rice husk biochar mixed soil was investigated at Bangabandhu Sheikh Mujibur Rahman Agricultural University (BSMRAU), Gazipur, Bangladesh, from January 21 to July 21, 2016. These organic materials were mixed with the local soil which is developed over the Madhupur Clay in the agro-ecological zone of Madhupur Tract. According to Bangladesh soil classification system, the study soil belongs to Salna series and classified as Shallow Red-Brown Terrace soil; while in USDA classification, it is under the order Inceptisols. The Madhupur Tract is a complex region comprised level upland, closely dissected terraces associated with shallow valleys. The study soil was collected from terrace which is well drained and clay loam in texture with $\mathrm{pH} 5.1$, organic carbon $9.0 \mathrm{~g} \mathrm{~kg}^{-1}$, and total nitrogen (N) $0.9 \mathrm{~g} \mathrm{~kg}^{-1}$. The climate of the study site is subtropical, wet, and humid. The organic materials used in the present study were selected based on their availability and potential for carbon sequestration. Cow dung is applied in the crop fields since the time immemorial; use of chicken manure in the recent past is very common in Bangladesh. Rice straw is available throughout the country as rice is our dominant crop, while rice husk biochar is thought to be a good quality amendment for increasing carbon stock in soil. Vermicompost is gaining popularity in Bangladesh because of the recent venture of organic farming. The physical and/or chemical properties of rice husk biochar, vermicompost, chicken manure, cow dung, and rice straw are given in Table 1. Rice husk biochar was prepared through partial burning in oxygen deficient condition at $350{ }^{\circ} \mathrm{C}$ temperature. One-month-old (accumulated in a pit and collected after 1 month) chicken manure and cow dung were procured from local poultry and dairy farms, respectively. Vermicompost was collected from Bangladesh Agricultural Research Institute, Gazipur. Rice straw was chopped into about $1 \mathrm{~cm}$ in size. All the materials were air dried and grinded in a machine and sieved by $2 \mathrm{~mm}$ mesh before use. 
Table 1 Physical and chemical properties of organic materials

\begin{tabular}{lllcc}
\hline Organic materials & Moisture $(\%)$ & Organic $\mathrm{C}\left(\mathrm{g} \mathrm{kg}^{-1}\right)$ & Total N $\left(\mathrm{g} \mathrm{kg}^{-1}\right)$ & C:N ratio \\
\hline Cow dung & 13.76 & 137.5 & 12.2 & 11.27 \\
Vermicompost & 17.64 & 121.5 & 9.8 & 12.39 \\
Chicken manure & 29.69 & 83.7 & 10.9 & 7.67 \\
Rice straw & 8.54 & 362.0 & 4.4 & 82.27 \\
Rice husk biochar & 9.25 & 313.0 & 3.7 & 84.59 \\
\hline
\end{tabular}

\section{Experimentation}

Two pot experiments were conducted in the laboratory of the Department of Soil Science, BSMRAU, Bangladesh. The experiment 1 (expt-1) was conducted in airtight plastic pots $(10 \mathrm{~cm} \times 15 \mathrm{~cm})$ for 26 weeks. There were five treatments comprising rice husk biochar, vermicompost, chicken manure, cow dung, and rice straw arranged in randomized complete blocks with six replications. Organic materials were mixed with soil at $2.5 \mathrm{~g} \mathrm{C} \mathrm{kg}^{-1}$ soil, and $0.5 \mathrm{~kg}$ soil was used in each pot. Sufficient amount of water was added to each pot for making the soil wet and kept moist throughout the study period by applying water weekly. The $\mathrm{CO}_{2}$ emission was measured by alkali $(\mathrm{NaOH})$ trapping and titrating with hydrochloric acid (Jain et al. 2003). The trap was prepared taking $80 \mathrm{ml}$ of $2 \mathrm{~N} \mathrm{NaOH}$ in a plastic bottle of $100 \mathrm{ml}$ in size. Such traps were placed in the pots for each treatment, and then the pots were covered with airtight lids. Empty pot with alkali alone was used as control. After 7 days, traps were collected at 10.00 a.m. covering with screw cap and replaced with new traps. Timing was maintained in such a way that $\mathrm{CO}_{2}$ absorption takes place for 7 days. Data were collected at 7 days interval up to 26 weeks.

The experiment 2 (expt-2) comprised of two factors, viz. organic materials and temperature regimes. Vermicompost, chicken manure, cow dung, and rice straw at $2.5 \mathrm{~g} \mathrm{C} \mathrm{kg}^{-1}$ soil for $0.4 \mathrm{~kg}$ soil pot $^{-1}$ were employed at six temperatures $\left(25,30,35,40,45\right.$, and $\left.50{ }^{\circ} \mathrm{C}\right)$ in randomized complete blocks using two replications. Each set of glass jars $(10 \mathrm{~cm} \times 10 \mathrm{~cm})$ containing mixtures of soil and organic materials was incubated for 10,20, and 30 days in an oven. Before placing in the oven, soil mixtures were made wet by adding sufficient amount of water, and the practice was continued at 5 days' interval. After each incubation period, soil from each glass jar was collected and analyzed for organic C.

\section{Soil analysis, $\mathrm{C}$ degradation rates, and $\mathrm{C}$ loss determination}

The chemical properties of soil and different organic materials were analyzed using standard methods such as soil pH by glass electrode (Jackson 1958), organic carbon by wet oxidation (Walkley and Black 1935), and total N by micro-Kjeldahl method (Black 1965).

Stanford and Smith (1972) provided $C=C_{0}\left(1-\mathrm{e}^{-k t}\right)$ equation for explaining $C$ degradation process, which was modified to calculate $C$ degradation rate constant $(k)$ as follows:

$k=\left(\frac{1}{t}\right) \times\left(\ln \left(C_{0}\right)-\ln \left(C_{0}-C\right)\right)$

where $C$ is the final and $C_{0}$ is the initial $C$ status; $t$ indicates time in day. The higher the $k$ value, the slower the degradation of organic materials in soils.

Carbon emission loss was calculated using the equation given below:

Emission loss of $\mathrm{C}(\%)=(\mathrm{C}$ emission from treatment $/$ (applied C + soil C) $) \times 100$.

\section{Limitations of the study}

There are some limitations or uncertainties associated with the present study. The trapping method of $\mathrm{CO}_{2}$ with airtight plastic container for 7 days may have changed soil microenvironment and thus soil respiration. However, it was similar to each treatment and thus no problem for comparison of treatment effects. Carbon degradation study under variable temperatures in oven might be another limitation where organic materials and soil mixtures were incubated for 10, 20, and 30 days, and slight variation in setting up temperature may occur. Therefore, limitations existed in the present study which needs to be addressed in future research.

\section{Statistical tool used for analysis}

Data were analyzed using Statistix version 10.0 software. The ANOVA and univariate analysis were done. Paired $t$ test was performed for the comparisons of soil properties between initial and after 26 weeks of incubation where the number of observations ( $n$ ) for each treatment/ organic material was six. Treatment means were compared by the least significant difference (LSD) test, and graphs were prepared using Microsoft Excel (Office 2007). 


\section{Results and discussion}

\section{Carbon mineralization and $\mathrm{CO}_{2}$ emission (expt-1)}

\section{Carbon dioxide emission}

The emission of $\mathrm{CO}_{2}$ varied among treatments (Fig. 1a). The $\mathrm{CO}_{2}$ emission was the maximum at 5 th weeks of incubation for all organic materials except rice husk biochar which was continuously in decreasing trend. After 5th week, the trend of $\mathrm{CO}_{2}$ emission decreased with irregular meandering fashion until 21 st week and then dropped down sharply to the lowest level of emission of 27-34 mg week ${ }^{-1} \mathrm{~kg}^{-1}$ soil for all organic materials. The maximum rate of $\mathrm{CO}_{2}$ emission was found in chicken manure (410.67 mg week ${ }^{-1} \mathrm{~kg}^{-1}$ soil) at 5 th week of incubation followed by rice straw $\left(374 \mathrm{mg} \mathrm{CO}_{2}\right.$ week $^{-1}$ $\mathrm{kg}^{-1}$ soil), cow dung (211 mg $\mathrm{CO}_{2}$ week ${ }^{-1} \mathrm{~kg}^{-1}$ soil), vermicompost (208 $\mathrm{mg} \mathrm{CO}$ week $^{-1} \mathrm{~kg}^{-1}$ soil), and rice husk biochar (116 mg CO 2 week ${ }^{-1} \mathrm{~kg}^{-1}$ soil). The lowest $\mathrm{CO}_{2}$ emission was recorded from rice husk biochar treatment.

Generally, about 1 month is needed for maximum microbial decomposition of added organic materials that was also found true in the present study. The $\mathrm{CO}_{2}$ is released from the soil through respiration of different flora, fauna, and plant roots mainly at surface soil. Soil microflora contributes $99 \%$ of the $\mathrm{CO}_{2}$ emission from soil because of organic matter decomposition (Reichle et al. 1975). Chicken manure had relatively greater amounts of total $\mathrm{N}$ and the lowest $\mathrm{C}: \mathrm{N}$ ratio (Table 1) that favored higher release of $\mathrm{CO}_{2}$ compared to other tested organic materials. Manures with higher $\mathrm{N}$ content and moisture undergo rapid microbial decomposition and tremendously increase $\mathrm{CO}_{2}$ emission ( $\mathrm{Ni}$ et al. 2010; Rahman et al. 2016). It was reported that higher labile $\mathrm{C}$ containing organic materials enhances $\mathrm{CO}_{2}$ emission resulting in less $\mathrm{C}$ accumulation in soil (Sylvia et al. 2005). Since we have found more $\mathrm{CO}_{2}$ emission from chicken manure, it might have contained higher amount of labile $\mathrm{C}$.

\section{Cumulative $\mathrm{CO}_{2}$ emission and $\mathrm{C}$ degradation constants}

Cumulative emission of $\mathrm{CO}_{2}$ as well as $\mathrm{C}$ at the end of 26 weeks of incubation period varied significantly because of variable $\mathrm{C}$ sources used (Table 2). During 26th week of incubation, the lowest cumulative $\mathrm{CO}_{2}$ emission (2044 mg $\mathrm{CO}_{2} \mathrm{~kg}^{-1}$ ) was observed in rice husk biochar treatment and the highest in chicken manure (5054 mg $\left.\mathrm{CO}_{2} \mathrm{~kg}^{-1}\right)$. The cumulative $\mathrm{CO}_{2}$ emissions from rice straw, vermicompost, and cow dung mixed soils were 4775, 3122, and $3083 \mathrm{mg} \mathrm{CO}_{2} \mathrm{~kg}^{-1}$, respectively. The trends of cumulative $\mathrm{CO}_{2}$ emissions are shown in Fig. 1b. Rates of $\mathrm{C}$ emission from organic materials mixed soil $\left(\mathrm{mg} \mathrm{C} \mathrm{kg}^{-1}\right.$ $\left.\mathrm{d}^{-1}\right)$ and applied carbon $\left(\mathrm{g} \mathrm{C} \mathrm{g}^{-1} \mathrm{~d}^{-1}\right)$ followed similar trends of cumulative $\mathrm{CO}_{2}$ emission (Table 2). Carbon emission loss was significantly higher in chicken manure (19.69\%)- and rice straw (18.60\%)-treated soils compared to other treatments, while the difference in $\mathrm{C}$ loss between cow dung (12.01\%) and vermicompost (12.16\%) was insignificant (Table 2). Carbon loss in rice husk biochartreated soil $(7.96 \%)$ was the lowest, which is less than half of the loss observed in chicken manure and rice straw treatments. However, the highest $\mathrm{CO}_{2}$ emission was observed with cow dung by Rahman et al. (2016) under field conditions.

Different $\mathrm{C}$ sources significantly influenced $\mathrm{C}$ degradation rates $(P<0.05)$. The $\mathrm{C}$ degradation rate constants (k) varied from 0.0078 to $0.0139 \mathrm{~d}^{-1}$ (Table 2). The highest $k$ value was found in the rice husk biochar-treated soil (0.0139), while the lowest was in the rice straw-treated soil (0.0078). The higher the $k$ value, the slower is the degradation of that material, i.e., degradation of rice husk biochar is slower compared to rice straw which logically corresponds with their respective cumulative $\mathrm{CO}_{2}$ emission
Fig. $1 \mathrm{CO}_{2}$ emission from different organic materials during 26 weeks of incubation: $\mathbf{a}$ trend and $\mathbf{b}$ cumulative emission. $R H B$ rice husk biochar, $C D$ cow dung, $V C$ vermicompost, $C M$ chicken manure, $R S$ rice straw)
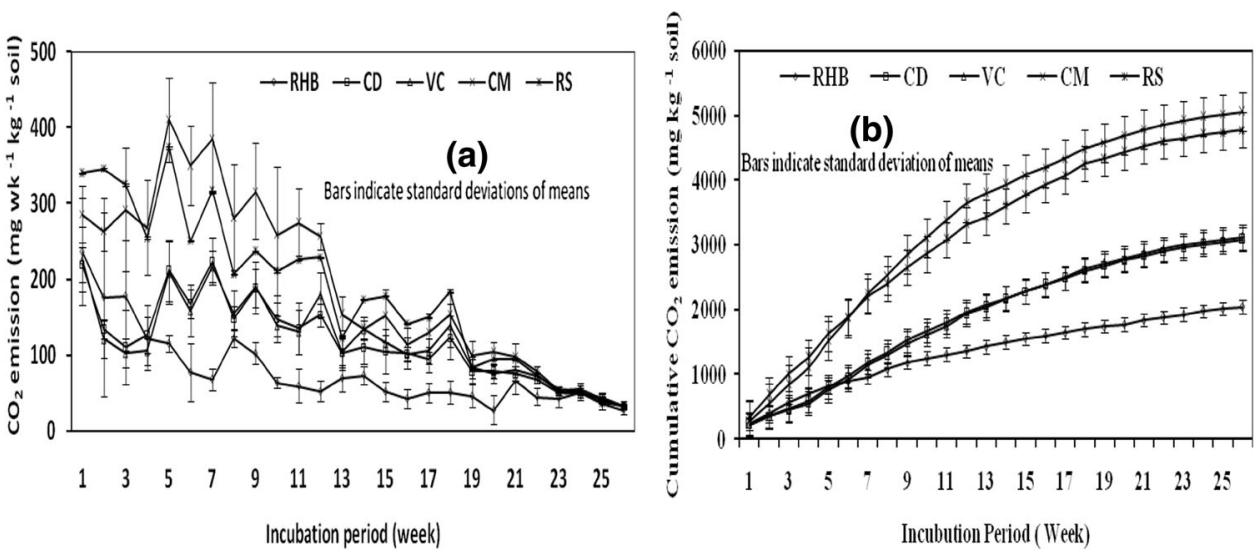
Table 2 Cumulative $\mathrm{CO}_{2}$ emission and $\mathrm{C}$ degradation rate constant for added organic materials

\begin{tabular}{|c|c|c|c|c|c|c|}
\hline Treatment & $\begin{array}{l}\text { Cumulative } \mathrm{CO}_{2} \\
\text { emission }\left(\mathrm{mg} \mathrm{kg}^{-1}\right. \\
\left.26 \mathrm{wk}^{-1}\right)\end{array}$ & $\begin{array}{l}\text { Equivalent } \mathrm{C} \\
\text { emission }\left(\mathrm{mg} \mathrm{kg}^{-1}\right. \\
\left.26 \mathrm{wk}^{-1}\right)\end{array}$ & $\begin{array}{l}\text { Rate of C } \\
\text { emission } \\
\left(\mathrm{mg} \mathrm{kg}^{-1} \mathrm{~d}^{-1}\right)\end{array}$ & $\begin{array}{l}\text { Rate of } \mathrm{C} \text { emission } \\
\left(\mathrm{g} \mathrm{C} \mathrm{g}^{-1} \mathrm{C} \text { applied }\right. \\
\left.\mathrm{d}^{-1}\right)\end{array}$ & $\begin{array}{l}\text { Rate of C } \\
\text { emission loss } \\
(\%)\end{array}$ & $\begin{array}{l}\mathrm{C} \text { degradation } \\
\text { rate constant, } \\
k\left(\mathrm{~d}^{-1}\right)\end{array}$ \\
\hline RHB + soil & $2043.98 \mathrm{c}$ & $557.4 \mathrm{c}$ & $3.06 \mathrm{c}$ & $0.000611 \mathrm{c}$ & $7.96 \mathrm{c}$ & $0.0139 a$ \\
\hline $\mathrm{CD}+$ soil & $3083.00 \mathrm{~b}$ & $840.8 b$ & $4.62 b$ & $0.000922 \mathrm{~b}$ & $12.01 \mathrm{~b}$ & $0.0115 b$ \\
\hline $\mathrm{VC}+$ soil & $3121.58 b$ & $851.3 b$ & $4.68 b$ & $0.000934 b$ & $12.16 \mathrm{~b}$ & $0.0105 \mathrm{bc}$ \\
\hline $\mathrm{CM}+$ soil & $5054.37 \mathrm{a}$ & $1378.5 a$ & $7.57 \mathrm{a}$ & $0.00151 \mathrm{a}$ & $19.69 \mathrm{a}$ & $0.0088 \mathrm{~cd}$ \\
\hline $\mathrm{RS}+$ soil & $4774.58 \mathrm{a}$ & $1302.2 \mathrm{a}$ & $7.15 \mathrm{a}$ & $0.00143 \mathrm{a}$ & $18.80 \mathrm{a}$ & $0.0078 \mathrm{~d}$ \\
\hline $\begin{array}{c}\text { Mean SE } \\
( \pm)\end{array}$ & 207.45 & 56.58 & 0.311 & 0.000062 & 0.8084 & 0.00011 \\
\hline $\mathrm{CV}(\%)$ & 9.94 & 9.94 & 9.94 & 9.94 & 9.94 & 18.23 \\
\hline
\end{tabular}

$R H B$ rice husk biochar, $C D$ cow dung, $V C$ vermicompost, $C M$ chicken manure, $R S$ rice straw

Different letters in a column indicate significant differences among treatments

(Table 2). Carbon degradation of different materials varies depending on the nature and types of organic residues and prevailing environmental conditions. Different researchers found a wide range of $\mathrm{C}$ degradation rate constants of different materials, but it is very unusual of reproducing similar data as experimental setup and environmental conditions are widely varied from one to another. Jorgensen (1979) reported $k$ values of $0.00001-0.0008$ for mineral soils, while Rahman (2013a) observed $k$ values from 0.000429 to 0.005104 for different manures and rice straw. Rice husk biochar might contain more stable $\mathrm{C}$ as it is a pyrolyzed by-product and thereby reduces $\mathrm{CO}_{2}$ emission from amended soil. Carbon and $\mathrm{N}$ contents of organic materials influence microbial decomposition, and thus release of $\mathrm{CO}_{2}$ depends on $\mathrm{C}: \mathrm{N}$ ratios of organic materials applied to soil (Rahman 2013b). The C:N ratio of chicken manure was significantly lower than cow dung, rice straw, and rice husk biochar that favored greater release of $\mathrm{CO}_{2}$ (Rahman 2013a; Rahman et al. 2016). The higher C:N ratio containing materials need several generations of microorganisms and obviously longer time for its decomposition. Microorganisms use $\mathrm{C}$ as energy source and their growth. For example, $50 \%$ of biomass of bacteria, fungi, and actinomycetes are C (Boyd 1995) indicating that small amount of $\mathrm{C}$ is released into the soil during decomposition.

\section{Influence of different organic materials on soil properties}

Rice husk biochar, cow dung, vermicompost, chicken manure, and rice straw were found effective in improving soil properties. All the materials were alkaline in nature (pH 7.1-7.6), and mixing these materials with soil changed soil properties (Table 3). After 26 weeks of incubation, soil $\mathrm{pH}, \mathrm{N}$, and $\mathrm{P}$ significantly increased, while organic $\mathrm{C}$ decreased significantly because of its loss as $\mathrm{CO}_{2}$ emission.
Degradation of organic material releases organic anions, which plays a major role in bonding aluminum ions and helps in neutralizing soil acidity and thus soil $\mathrm{pH}$ may increase. The increment in soil $\mathrm{pH}$ with chicken manuretreated soil was contributed by calcium $(\mathrm{Ca})$ present in it. The poultry feeds contain higher amount $\mathrm{Ca}$, and eventually this Ca transferred to chicken manure. We have found increased soil $\mathrm{pH}$ because of chicken manure, which was also reported by Heidi et al. (2011) and Rahman (2013b). Materechera and Mkhabela (2002) reported that the effectiveness of chicken manure as liming material is $26 \%$ compared to lime. The increase in $\mathrm{pH}$ from cow dung amendment was related to its buffering capacity and release of organic acids (Whalen et al. 2000; Olayinka 2001; Ogbodo 2011). Organic fertilizer increases cation exchange capacity resulting in higher base saturation, and thus relative amount of acid cations are neutralized. The vermicompost increases soil $\mathrm{pH}$ because calciferous glands of earthworms release carbonic anhydrase, which catalyzes the fixation of $\mathrm{CO}_{2}$ as $\mathrm{CaCO}_{3}$ and thus increases soil $\mathrm{pH}$ (Kale and Krishnamoorthy 1982). The rice husk biochar and chicken manure were more efficient in increasing soil $\mathrm{pH}$ levels.

\section{Carbon mineralization under different temperature regimes (expt-2)}

\section{Decrease in $C(\%)$ and its degradation rates $(k)$}

Decrease in $\mathrm{C}$ contents in soils treated with organic materials under different temperatures varied significantly (Table 4). Irrespective of incubation periods, the highest percentage of $\mathrm{C}$ decrement was observed in chicken manure and the lowest in rice straw-treated soils. The rates of $\mathrm{C}$ decrease in chicken manure-treated soils were 1.56, 1.87, and $2.47 \%$ in 10,20 , and 30 days of incubation, 
Table 3 Properties of organic materials at the initial and after 26 weeks of incubation period

\begin{tabular}{|c|c|c|c|c|c|c|c|c|}
\hline \multirow[t]{2}{*}{ Organic materials } & \multicolumn{2}{|l|}{$\mathrm{pH}$} & \multicolumn{2}{|c|}{ Organic C (\%) } & \multicolumn{2}{|c|}{ Nitrate $\mathrm{N}\left(\mathrm{mg} \mathrm{kg}^{-1}\right)$} & \multicolumn{2}{|c|}{ Available $\mathrm{P}\left(\mathrm{mg} \mathrm{kg}^{-1}\right)$} \\
\hline & Initial & After 26 weeks & Initial & After 26 weeks & Initial & After 26 weeks & Initial & After 26 weeks \\
\hline RHB + soil & $6.48 b$ & $6.76 \mathrm{a}$ & $2.53 \mathrm{a}$ & $2.32 b$ & $3.21 \mathrm{~b}$ & $4.50 \mathrm{a}$ & 19.03 & 19.44 \\
\hline $\mathrm{CD}+$ soil & $6.38 \mathrm{~b}$ & $6.46 \mathrm{a}$ & $2.96 \mathrm{a}$ & $2.55 b$ & $6.55 b$ & $8.52 \mathrm{a}$ & $23.39 b$ & $24.65 \mathrm{a}$ \\
\hline $\mathrm{VC}+$ soil & $6.37 \mathrm{~b}$ & $6.63 \mathrm{a}$ & $2.88 \mathrm{a}$ & $2.18 \mathrm{~b}$ & $7.93 b$ & $9.64 \mathrm{a}$ & $21.02 b$ & $22.98 \mathrm{a}$ \\
\hline $\mathrm{CM}+$ soil & $6.46 \mathrm{~b}$ & $6.77 \mathrm{a}$ & $2.93 \mathrm{a}$ & $2.40 \mathrm{~b}$ & $9.24 b$ & $11.25 \mathrm{a}$ & $39.00 \mathrm{~b}$ & $40.33 a$ \\
\hline RS + soil & $6.45 b$ & $6.61 \mathrm{a}$ & $3.01 \mathrm{a}$ & $2.33 b$ & $3.63 b$ & $5.12 \mathrm{a}$ & 7.34 & 7.58 \\
\hline
\end{tabular}

$R H B$ rice husk biochar, $C D$ cow dung, $V C$ vermicompost, $C M$ chicken manure, $R S$ rice straw

Paired $t$ test was done using the number of observation six for each treatment

Different letters in a row under each parameter (difference between initial and after 26 weeks) indicate significant differences

Table 4 Decrease of carbon in organic materials under different temperatures and incubation periods

\begin{tabular}{llll}
\hline Organic materials & \multicolumn{3}{l}{ Carbon decreases $(\%)$} \\
\cline { 2 - 4 } & 10 days & 20 days & 30 days \\
\hline Cow dung & $1.34 \mathrm{a}$ & $1.78 \mathrm{ab}$ & $2.56 \mathrm{a}$ \\
Vermicompost & $1.38 \mathrm{a}$ & $1.71 \mathrm{ab}$ & $2.37 \mathrm{ab}$ \\
Chicken manure & $1.56 \mathrm{a}$ & $1.87 \mathrm{a}$ & $2.47 \mathrm{ab}$ \\
Rice straw & $1.12 \mathrm{~b}$ & $1.62 \mathrm{~b}$ & $2.32 \mathrm{a}$ \\
Mean SE $( \pm)$ & 0.11 & 0.26 & 0.25 \\
Temperature $\left({ }^{\circ} \mathrm{C}\right)$ & & & \\
25 & $0.86 \mathrm{~d}$ & $1.11 \mathrm{~d}$ & $1.78 \mathrm{c}$ \\
30 & $1.10 \mathrm{~cd}$ & $1.70 \mathrm{bc}$ & $2.28 \mathrm{~b}$ \\
35 & $1.32 \mathrm{bc}$ & $1.63 \mathrm{c}$ & $2.20 \mathrm{~b}$ \\
40 & $1.58 \mathrm{ab}$ & $1.94 \mathrm{ab}$ & $2.45 \mathrm{~b}$ \\
45 & $1.57 \mathrm{ab}$ & $1.99 \mathrm{a}$ & $2.30 \mathrm{~b}$ \\
50 & $1.66 \mathrm{a}$ & $2.08 \mathrm{a}$ & $3.48 \mathrm{a}$ \\
Mean SE $( \pm)$ & 0.13 & 0.21 & 0.11 \\
Organic materials $\times$ temp & NS & NS & $*$ \\
CV $(\%)$ & 19.21 & 14.40 & 10.75 \\
\hline
\end{tabular}

NS non-significant

*Significant at $5 \%$ level

Different letters in a column under treatment factors indicate significant difference

respectively, while these values for rice straw were 1.12, 1.62 , and $2.32 \%$, respectively. The amount of $\mathrm{C}$ decreased with the increase of incubation periods. Irrespective of organic materials and temperature, the $\mathrm{C}$ decrement rates under different incubation periods followed the order of $30>20>10$ days. The temperature influenced $\mathrm{C}$ reduction of different residues significantly, and with the increment of incubation time, the higher amount of $\mathrm{C}$ was lost (Table 4).

Carbon decrement rate was the lowest at $25{ }^{\circ} \mathrm{C}$ and the highest at $50{ }^{\circ} \mathrm{C}$ irrespective of incubation periods. The rates of $\mathrm{C}$ decrease at $25^{\circ} \mathrm{C}$ were $0.86,1.11$, and $1.78 \%$ in
10, 20, and 30 days of incubation periods, respectively, while these values for $50{ }^{\circ} \mathrm{C}$ were $1.66,2.08$, and $3.48 \%$, respectively. The rates of SOM decomposition mainly depend upon the interactions among soil biota, temperature, moisture, and chemical and physical composition of soils as well as types of organic materials added (Taylor et al. 2009). The interaction effect of organic residues and temperature on decrease of $\mathrm{C}(\%)$ at 30 days of incubation was significant (Table 5). The highest decrement rate $(3.82 \%)$ was found in vermicompost at $50{ }^{\circ} \mathrm{C}$, which insignificantly varied with cow dung $(3.72 \%)$ and rice straw $(3.32 \%)$ at the same temperature. It was observed that the differences in $\mathrm{C}$ decrease among different organic materials within same temperature are insignificant in many cases, while in most of the cases organic matter showed significance under different degrees of temperature. This signifies the contribution of temperature in enhanced mineralization of organic materials added to soil.

Carbon degradation rates were found significantly different among organic materials mixed soil (Table 6). The effect of temperature on mineralization of organic matter was also found significant. In the present study, different organic materials had variable $\mathrm{C}: \mathrm{N}$ ratios. Their $\mathrm{C}: \mathrm{N}$ ratios were different as $\mathrm{N}$ contents were variable, which attributed to different degradation rate constants (Table 6). Among different organic materials, rice straw provided significantly the highest degradation rate, which revealed the slower rates of decomposition of rice straw. The $\mathrm{C}$ degradation rate constants in cow dung, chicken manure, and vermicompost-treated soils were statistically similar. Comparatively lower rates were observed in chicken manure-treated soils. It is worth mentioning that $\mathrm{C}$ degradation rates in all organic materials decreased with the increase of incubation periods, which is also applicable in case of temperature (Table 6). Temperature enhanced the decomposition of organic matter in soil, which is evinced as $k$ values decreased with the increased temperature. The 
Table 5 Interaction effect of organic materials and temperature on $\mathrm{C}$ decrease $(\%)$ at 30 days of incubation

\begin{tabular}{lllllll}
\hline Organic materials & \multicolumn{5}{l}{ Temperature $\left({ }^{\circ} \mathrm{C}\right)$} \\
\cline { 2 - 7 } & 25 & 30 & 35 & 40 & 45 & 50 \\
\hline Cow dung & $1.68_{\mathrm{c}}^{\mathrm{ab}}$ & $2.53_{\mathrm{b}}$ & $2.36_{\mathrm{b}}$ & $2.70_{\mathrm{b}}^{\mathrm{a}}$ & $2.36_{\mathrm{b}}^{\mathrm{b}}$ & $3.72_{\mathrm{a}}^{\mathrm{a}}$ \\
Vermicompost & $1.73_{\mathrm{d}}^{\mathrm{ab}}$ & $2.25_{\mathrm{bcd}}$ & $1.91_{\mathrm{cd}}$ & $2.43_{\mathrm{bc}}^{\mathrm{ab}}$ & $2.08_{\mathrm{bcd}}^{\mathrm{bc}}$ & $3.82_{\mathrm{a}}^{\mathrm{a}}$ \\
Chicken manure & $1.53_{\mathrm{c}}^{\mathrm{b}}$ & $2.38_{\mathrm{b}}$ & $2.21_{\mathrm{b}}$ & $2.52_{\mathrm{b}}^{\mathrm{ab}}$ & $3.07_{\mathrm{a}}^{\mathrm{a}}$ & $3.07_{\mathrm{a}}^{\mathrm{b}}$ \\
Rice straw & $2.15_{\mathrm{bc}}^{\mathrm{a}}$ & $2.32_{\mathrm{b}}$ & $2.32_{\mathrm{b}}$ & $2.14_{\mathrm{bc}}^{\mathrm{c}}$ & $1.66_{\mathrm{c}}^{\mathrm{c}}$ & $3.32_{\mathrm{a}}^{\mathrm{a}}$ \\
\hline
\end{tabular}

$\% \mathrm{CV}=10.75$ and Mean SE $( \pm)=0.13$

Different superscript letters indicate significant difference among the values observed in column under each temperature with different organic materials, while different subscript letters indicate significant difference among the values observed in row under each organic material with different temperature using the least significant test at $P \leq 0.05$
Table 6 Carbon degradation rate constant as influenced by organic materials and temperatures at various incubation periods

\begin{tabular}{llll}
\hline Organic materials & \multicolumn{3}{l}{ C degradation rate constant $(k)$} \\
\cline { 2 - 4 } & 10 days & 20 days & 30 days \\
\hline Cow dung & $0.4370 \mathrm{ab}$ & $0.2039 \mathrm{ab}$ & 0.1231 \\
Vermicompost & $0.4317 \mathrm{bc}$ & $0.2041 \mathrm{ab}$ & 0.1260 \\
Chicken manure & $0.4200 \mathrm{c}$ & $0.2006 \mathrm{~b}$ & 0.1244 \\
Rice straw & $0.4517 \mathrm{a}$ & $0.2072 \mathrm{a}$ & 0.1262 \\
Mean SE $( \pm)$ & 0.00732 & 0.00272 & 0.00151 \\
Temperature $\left({ }^{\circ} \mathrm{C}\right)$ & & & \\
25 & $0.4764 \mathrm{a}$ & $0.2257 \mathrm{a}$ & $0.1348 \mathrm{a}$ \\
30 & $0.4515 \mathrm{~b}$ & $0.2038 \mathrm{bc}$ & $0.1247 \mathrm{~b}$ \\
35 & $0.4337 \mathrm{bc}$ & $0.2060 \mathrm{~b}$ & $0.1273 \mathrm{~b}$ \\
40 & $0.4177 \mathrm{~cd}$ & $0.1972 \mathrm{~cd}$ & $0.1238 \mathrm{~b}$ \\
45 & $0.4164 \mathrm{~cd}$ & $0.1960 \mathrm{~d}$ & $0.1266 \mathrm{~b}$ \\
50 & $0.4149 \mathrm{~d}$ & $0.1950 \mathrm{~d}$ & $0.1123 \mathrm{c}$ \\
Mean SE $( \pm)$ & 0.008976 & 0.003338 & 0.001857 \\
Materials $\times$ temperature & $\mathrm{NS}$ & $\mathrm{NS}$ & $*$ \\
$\mathrm{CV}(\%)$ & 4.13 & 3.27 & 2.97 \\
\hline
\end{tabular}

NS non-significant

*Significant at $5 \%$ level

Different letters in a column under treatment factors indicate significant difference

C degradation rate constants, $k$, at $25{ }^{\circ} \mathrm{C}$ were 0.4764 , 0.2257 , and 0.1348 in 10,20 , and 30 days of incubation period, respectively. At $50{ }^{\circ} \mathrm{C}$, the $k$ values were 0.4149 , 0.1950 , and 0.1123 , respectively.

The interaction effect of organic residues and temperature on $\mathrm{C}$ degradation rate constant, $k$, was found significant at 30 days of incubation only (Table 7). The lowest $k(0.1088)$ was found in vermicompost at $50{ }^{\circ} \mathrm{C}$ that insignificantly varied with cow dung (0.1097) and rice straw $(0.1135)$ at the same temperature which logically supports the corresponding $\mathrm{C}$ decrement rates provided in Table 5. Carbon degradation rate constants among different organic materials were found statistically similar at the temperature of 30,35 , and $40{ }^{\circ} \mathrm{C}$, while differences were observed at 25,45 , and $50{ }^{\circ} \mathrm{C}$. At the temperature of $25^{\circ} \mathrm{C}$, carbon degradation rate constant was found significantly lower in rice straw (0.1279) than that of cow dung, vermicompost, and chicken manure (Table 7). At the higher level of temperature $\left(45\right.$ and $\left.50{ }^{\circ} \mathrm{C}\right)$ degradation rates among different organic materials followed similar trends.

\section{Trends of $\mathbf{C}$ decrease under different organic materials and temperature regimes}

The $\mathrm{C}$ contents in different organic material mixed soil decreased with increasing temperature regimes. Although initial $\mathrm{C}$ contents in all organic materials were equal, variations were observed in the rates and fashions of mineralization. For cow dung treatment in 10 days' incubation period, the $\mathrm{C}$ content decreased with the increasing temperature up to $40{ }^{\circ} \mathrm{C}$ and then increased slightly (Fig. 2a). Similar trends were observed with 20 and 30 days of incubation period with exception at $50{ }^{\circ} \mathrm{C}$ under 30 days of incubation period where trend declined rapidly. More or less similar trends in $\mathrm{C}$ decrement under different temperature were found in vermicompost, chicken manure, and rice straw (Fig. 2b-d).

The importance of temperature sensitivity soil microbial processes on global dynamics of soil $\mathrm{C}$ pools has been reported by many authors (Anderson 1992; Zogg et al. 1997). Therefore, the responses of microbes to $C$ mineralization under high temperatures could be determined based on interaction between magnitude of microbial physiological responses and the attributes of SOM pools. Laboratory incubation studies with organic materials under controlled conditions have been used to quantify temperature-dependent utilization of cellulose, hemicelluloses, protein, starch, sugars, etc. (Howard and Howard 1979; Moore and Dalva 1986; Howard and Howard 1993). Labile $\mathrm{C}$ dictates mineralization of a material because it decomposes initially to a greater extent, and any increase in temperature reduces the duration of decomposition phase. 
Table 7 Interaction effect organic materials and temperature on $\mathrm{C}$ degradation rate $(k)$ at 30 days of incubation

\begin{tabular}{lllllll}
\hline Organic materials & \multicolumn{5}{l}{ Temperature $\left({ }^{\circ} \mathrm{C}\right)$} \\
\cline { 2 - 7 } & 25 & 30 & 35 & 40 & 45 & 50 \\
\hline $\mathrm{CD}$ & $0.1360_{\mathrm{a}}^{\mathrm{a}}$ & $0.1226_{\mathrm{b}}$ & $0.1248_{\mathrm{b}}$ & $0.1204_{\mathrm{b}}$ & $0.1248_{\mathrm{b}}^{\mathrm{c}}$ & $0.1097_{\mathrm{c}}^{\mathrm{ab}}$ \\
$\mathrm{VC}$ & $0.1358_{\mathrm{a}}^{\mathrm{a}}$ & $0.1265_{\mathrm{b}}$ & $0.1321_{\mathrm{ab}}$ & $0.1239_{\mathrm{b}}$ & $0.1290_{\mathrm{ab}}^{\mathrm{bc}}$ & $0.1088_{\mathrm{c}}^{\mathrm{b}}$ \\
$\mathrm{CM}$ & $0.1394_{\mathrm{a}}^{\mathrm{a}}$ & $0.1245_{\mathrm{bc}}$ & $0.1270_{\mathrm{b}}$ & $0.1227_{\mathrm{bcd}}$ & $0.1161_{\mathrm{d}}^{\mathrm{d}}$ & $0.1169_{\mathrm{cd}}^{\mathrm{a}}$ \\
$\mathrm{RS}$ & $0.1279_{\mathrm{b}}^{\mathrm{b}}$ & $0.1254_{\mathrm{b}}$ & $0.1254_{\mathrm{b}}$ & $0.1282_{\mathrm{b}}$ & $0.1366_{\mathrm{a}}^{\mathrm{ab}}$ & $0.1135_{\mathrm{c}}^{\mathrm{ab}}$ \\
\hline
\end{tabular}

$\% \mathrm{CV}=2.97$ and $\mathrm{SE}( \pm)=0.0037$

$C D$ cow dung, $V C$ vermicompost, $C M$ chicken manure, $R S$ rice straw

Different superscript letters indicate significant difference among the values observed in column under each temperature with different organic materials, while different subscript letters indicate significant difference among the values observed in row under each organic material with different temperature using the least significant test at $P \leq 0.05$
Fig. 2 Carbon reduction trends in different organic materials added soil: a cow dung, b vermicompost, $\mathbf{c}$ chicken manure, and $\mathbf{d}$ rice straw with temperature regimes and incubation periods
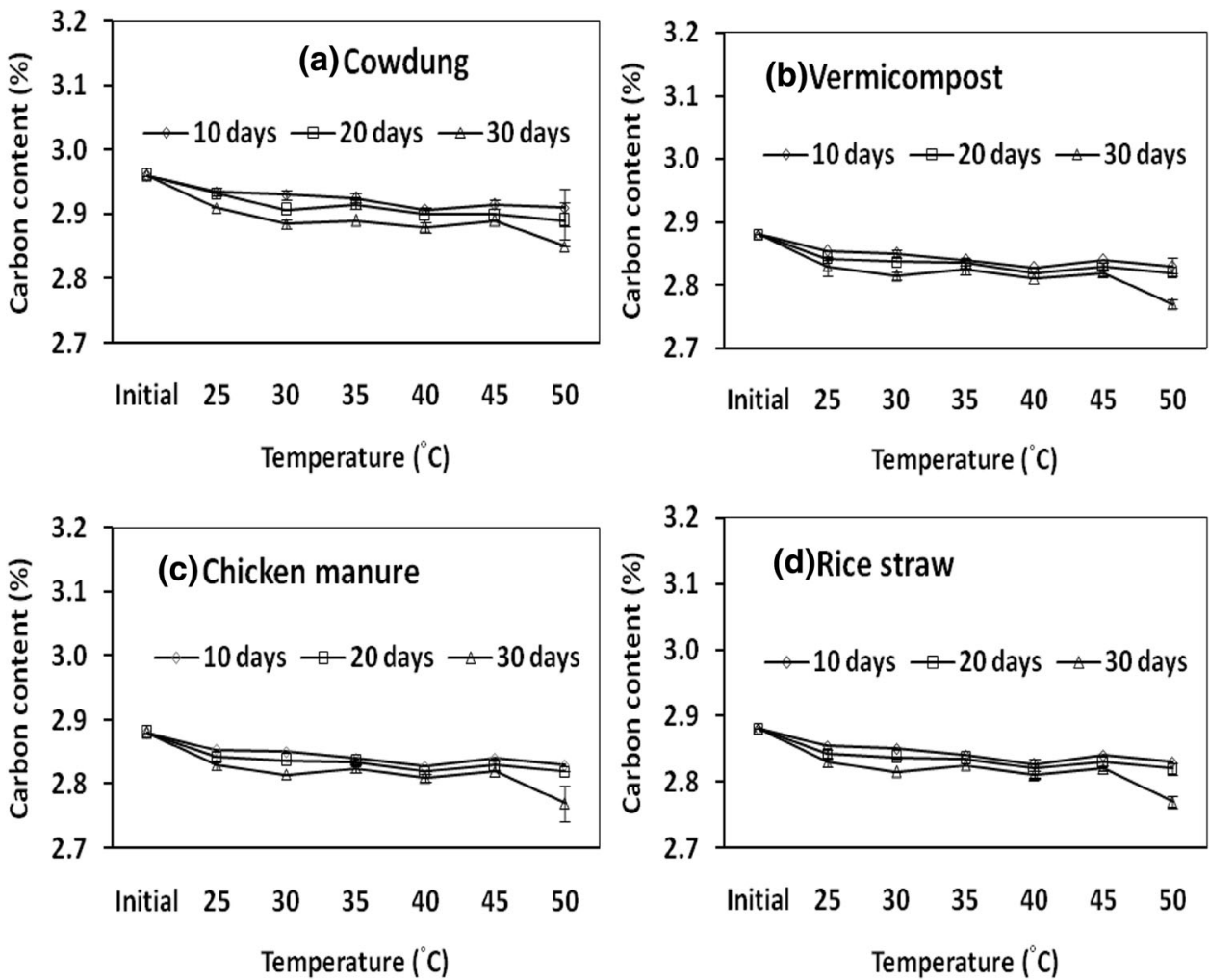

\section{Conclusions}

Carbon dioxide emission loss was found the maximum in chicken manure mixed soil followed by rice straw, vermicompost, cow dung, and rice husk biochar. Temperaturefavored mineralization of organic materials added to soil which indicates that global warming and climate change will make our soil more vulnerable in terms of $\mathrm{C}$ loss and thus reduction in soil productivity. Comparatively slower decomposition and corresponding less $\mathrm{CO}_{2}$ emission from rice husk biochar, cow dung, and vermicompost mixed soils qualify these organic materials as soil conditioners. Therefore, these organic materials can be recommended for farmers' practice that might improve soil health and reduce $\mathrm{CO}_{2}$ emission from agricultural soils.

Acknowledgements We greatly acknowledge Bangladesh Krishi Gobeshona Foundation (KGF) for financing this research activity through Modeling Climate Change Impact in Bangladesh Agriculture (CRP-II) project.

Open Access This article is distributed under the terms of the Creative Commons Attribution 4.0 International License (http://crea tivecommons.org/licenses/by/4.0/), which permits unrestricted use, distribution, and reproduction in any medium, provided you give appropriate credit to the original author(s) and the source, provide a link to the Creative Commons license, and indicate if changes were made. 


\section{References}

Agehara S, Warncke DD (2005) Soil alternate wetting and drying pure and temperature effects on nitrogen release from organic nitrogen sources. Soil Sci Soc Am J 69:1844-1855

Anderson JM (1992) Responses of soils to climate change. Adv Ecol Res 22:163-210. doi:10.1016/S0065-2504(08)60136-1

Black CA (1965) Soil plant relationship, 2nd edn. Wiley, New York, p 462

Boyd CE (1995) Bottom soils, sediment and pond aquaculture. Chapman \& Hall, New York, p 348

Cabrera ML, Dkisseland A, Vigil MF (2005) Nitrogen mineralization from organic materials: research opportunities. J Environ Qual 34:75-79

Conant RT, Ryan MG, Agren GI, Birge HE, Davidson EA, Eliasson PE, Evans SE, Frey SD, Giardina CP, Hopkins FM, Nen RH, Kirschbaum MUF, Lavallee JM, Feld JEL, Parton WJ, Steinweg JEM, Wallenstein MD, Wetterstedt JAM, Bradford MA (2011) Temperature and soil organic matter decomposition ratessynthesis of current knowledge and a way forward. Glob Change Biol 17:3392-3404

Davidson EA, Janssens IA (2006) Temperature sensitivity of soil carbon decomposition and feedbacks to climate change. Nature 440:165-172

Franzluebbers AJ, Doraiswamy PC (2007) Carbon sequestration and land degradation. Climate and land degradation, chapter 18 . Springer, Berlin, pp 343-358

Gnanavelrajah N, Shrestha RP, Schmidt-Vogtand D, Samarakoon L (2008) Carbon stock assessment and soil carbon management in agricultural land-uses in Thailand. Land Degrad Dev 19:242-256

Hassan W (2013) Carbon and nitrogen mineralization and dissolved organic matter potentials of two contrasting plant residues: effect of residue type, moisture and temperature. Acta Agriculturae Scandinavica. Soil Plant Sci 63(7):642-652

Heidi MW, He Z, Erich MS (2011) Effects of poultry manure amendment on phosphorus uptake by ryegrass, soil phosphorus fractions and phosphatase activity. Biol Fertil Soils 47:407-418. doi:10.1007/s00374-011-0546-4

Howard DM, Howard PJA (1979) Respiration of decomposing litter in relation to temperature and moisture: microbial decomposition of tree and shrub leaf litter. Oikos 33(3):457-465

Howard DM, Howard PJA (1993) Relationships between $\mathrm{CO}_{2}$ evolution, moisture-content and temperature for a range of soil types. Soil Biol Biochem 25:1537-1546

Jackson ML (1958) Soil chemical analysis. Prentice-Hall, Inc., Englewood Cliffs

Jain MC, Pathak H, Bhatia A (2003) Measurement of greenhouse emission from soil and developing emission inventories. In: Pathak H, Kumer S (eds) Soil and greenhouse effect monitoring and evaluation. CBS Publishers and Distributors, New Delhi, pp 65-78

Jorgensen SE (1979) Handbook of environmental data and ecological parameters. Pergamon Press, Oxford

Kale RD, Krishnamoorthy RV (1982) Cyclic fluctuations in the population and distribution of three species of tropical earthworms in farm yard garden in Bangalore. Rev d' Ecolgie et de Biol du Sol 19:61-71

Kundu S, Bhattacharyya R, Prakash V, Ghosh BN, Gupta HS (2006) Carbon sequestration and relationship between carbon addition and storage under rain fed soybean-wheat rotation in a sandy loam soil of the Indian Himalayas. Soil Tillage Res 92:87-95

Lal R (2004) Soil carbon sequestration to mitigate climate change. Geoderma 123:1-22. doi:10.1016/j.geoderma.2004.01.032
Lal R (2006) Enhancing crop yields in the developing countries through restoration of the soil organic carbon pool in agricultural lands. Land Degrad Dev 17:197-209

Lal R (2016) Soil health and carbon management. Food Energy Secur 5(4):212-222. doi:10.1002/fes3.96

Materechera SA, Mkhabela TS (2002) The effectiveness of lime, chicken manure and leaf litter ash in ameliorating acidity in a soil previously under black wattle (Acacia mearnsii) plantation. Biores Technol 85:9-16

Moore TR, Dalva M (1986) The influence of temperature and water table position on carbon dioxide and methane emissions from laboratory columns of peatland soils. J Soil Sci 44:651-664

Ni JQ, Heber AJ, Hanni SM, Lim TT, Diehl CA (2010) Characteristics of ammonia and carbon dioxide releases from layer hen manure. Br Poult Sci 51:326-334

Ogbodo EN (2011) Effect of crop residue on soil chemical properties and rice yield on an Ultisol at Abakaliki, Southeastern Nigeria. World J Agric Sci 7(1):13-18

Olayinka A (2001) Effects of co-applied cow dung and organic nitrogen on microbial respiration in soil under laboratory conditions. Commun Soil Sci Plant Anal 32(19 \& 20):3229-3242

Rahman MM (2013a) Carbon dioxide emission from soil. Agric Res 2(2):132-139

Rahman MM (2013b) Nutrient-use and carbon accumulation efficiencies in soils from different organic wastes in rice and tomato cultivation. Commun Soil Sci Plant Anal 44(9):1457-1471

Rahman F, Rahman MM, Rahman GKMM, Saleque MA, Hossain ATMS, Miah MG (2016) Effect of organic and inorganic fertilizers and rice straw on carbon sequestration and soil fertility under a rice-rice cropping pattern. Carbon Manag 7(1-2):41-53

Rastogi M, Singh S, Pathak H (2002) Emission of carbon dioxide from soil. Curr Sci 82:510-517

Reichle DE, McBrayer JF, Ausmus BS (1975) Progress in soil zoology. Academic Publishing, Prague, pp 283-292

Russell AE, Larid DA, Parkin TB, Mallarino AP (2005) Impact of nitrogen fertilization and cropping system on carbon sequestration in Midwestern Mollisols. Soil Sci Soc Am J 69:413-422

Stanford G, Smith SJ (1972) Nitrogen mineralization potentials of soils. Soil Sci Soc Am Proc 36:465-472

Sylvia DM, Fuhrmann JJ, Hartel PG, Zuberer DA (2005) Principles and applications of soil microbiology, 2nd edn. Pearson Prentice Hall, New Jersey, p 672

Taylor LL, Leake JR, Quirk J, Hardy K, Banwart SA, Beerling DJ (2009) Biological weathering and the long-term carbon cycle: integrating mycorrhizal evolution and function into the current paradigm. Geobiology 7:171-191

van Gestel M, Ladd JN, Amato M (1991) Carbon and nitrogen mineralization from two soils of contrasting texture and microaggregate stability: influence of sequential fumigation, drying and storage. Soil Biol Biochem 23:313-322

Walkley AC, Black TA (1935) Estimation of soil organic carbon by chromic acid titration method. Soil Sci 47:29-38

Whalen J, Chang C, Clayton G, Carefoot J (2000) Cattle manure organic materials can increase the $\mathrm{pH}$ of acidic soils. Soil Sci Soc Am J 64:962-966

Zogg GP, Zak DR, Ringelberg DB, MacDonald NW, Pregitze KS, White DC (1997) Compositional and functional shifts in microbial communities due to soil warming. Soil Sci Soc Am J 61:475-481

\section{Publisher's Note}

Springer Nature remains neutral with regard to jurisdictional claims in published maps and institutional affiliations. 